\title{
Occupy Globalization
}

\author{
Ben Agger, Timothy W. Luke
}

If Baudrillard is correct and everything is, or soon will become, a "brand," then we need to revisit our ability to "occupy globalization," one of the trendiest brands inside the Beltway, among G7 leaders, and even, of course, in academia, where the faculty experts and administrators of universities also are clamoring to get on board with globality. "Occupy" itself might well soon become a brand, doing our thinking for us, but we are skeptical that it has happened yet. Right now, it seems to operate as a displaced expression of globality's occupation of the thought and lived possibilities for a good conscience of "the one percent," if only because Occupy doesn't theorize itself beyond noticing that capitalist accumulation has left out nearly everyone else constituting those being dispossessed in "the ninety-nine percent."

The "globalization" brand has at least two perniciously intertwined meanings. Since the 1980s and 1990s, there has been a rapid scramble among corporations and governments to reduce, reconfigure or even remove most existing trade barriers. The commodification of national currencies, rationalization of international trade and even weakening of national boundaries all articulate this aspect of globalization. Under the influence of a generation of economists enthralled by Ayn Rand, von Hayek, Milton Friedman, and von Mises, "neo-liberalism" is the strange name given to these efforts to allow the price mechanism in market exchange to marketize every last element of everyday life (or less strange, if one recalls C.B. Macpherson's Political Theory of Possessive Individualism (1970) and his argument that liberalism buttresses capitalism). Marx and Engels fully anticipated this "global turn" as they predicted flights of capitalists battering down such "Chinese walls" as the bourgeoisie sought more sources of cheap labor and more expansive world markets. Thus, their ambivalent insight that globalization "compels all nations, on pain of extinction, to adopt the bourgeois mode of production; it compels them to introduce what it calls civilization into their midst, i.e., to become bourgeois themselves. In one word, it creates a world after its own image."

The other meaning of globalization recalls the recent 2008 summer Olympics in China, where we see the profitable fruition of three decades of Deng Xiaoping's most crucial policy directive to the toiling masses: "enrich yourselves" by bringing all of the beginnings of American fast-food culture to the swelling middle class in the PRC's big cities and coastal provinces, including key globalizing media such as automobiles, high-rise condos, television and the Internet. China resists some aspects of this globalization when and where the Chinese Communist Party and state authorities still don't permit Facebook, which boasts nearly a billion world 'friends.' The Internet drives both aspects of globalization, connecting producers and consumers of anything, anytime, anywhere, which delivers $24 \times 7$ the wares and diversions of what Horkheimer and Adorno first called the culture industry.

And thus the globalization brand has crowded out the older brands of the welfare state, which, for 50 years staved off deep recession and real depression as a mode of collective social economy, removes trade barriers and spreads the wonders of American media culture with its global shopping channels, six-lane expressway automobility and a cuisine known worldwide as McDonald's. Marx called this "capitalism" and Hardt and Negri call it "empire." Now, Marx "got" neoliberalism and perhaps he would have gotten the Internet, Facebook, smart phones and McDonald's. He didn't foresee Keynes, FDR and the welfare state, and thus he thought that a single major depression could, under the right conditions, spell the end of capitalism in a convulsive general crisis. It didn't or, rather, hasn't yet. But, had he foreseen the policy tools employed by New Deal state intervention, which lasted as part of the welfare state brand until Reagan and Thatcher, one wonders if he would have been surprised by the recent marketizing, anti-tariff turn that could be said to be a deboundarying of once strong nation-states in the already modernized regions of the capitalist world-system. 
Indeed, Marx anticipated the contours of a postmodern capitalism, as he clearly announces when he and Engels talk in the Manifesto about all solidity melting into air. He foresaw the ethereal images of the computer screen and television replacing (or at least transforming) a harder "reality" over 150 years ago, even if he didn't write extensively about the vapid distractions that follow from tethering the information, communication and entertainment technologies of the contemporary culture industry to the services of global exchange. Marx might have been unsurprised that Facebook would go public, Detroit sells automobiles by bringing Internet connectivity and mega-capacity hard drives into the cars' cockpit consoles, or that the many variants of social media would become an opiate of the masses who are, now as before, alienated in their labor.

The academicization of "globalization" makes the mistake of all positivism: in describing, it endorses. The Frankfurt School identified this conflation as a central feature of an "affirmative culture." Noticing that the Internet erases boundaries quickly becomes a celebration of deboundarying, when, in fact, there are still profound, and most likely intractable, remaining differences in wealth, power and control among classes, nations, regions. To be sure, capitalism/empire/globalization are, as ever, contradictory. The globalizing tentacles of the Internet have been providing a medium, not only for e-commerce and cultural sedation, but also for an Arab Spring and Occupy Wall Street. The "global" here definitely is not a solution. It is instead the problem; think of sweatshops, outsourcing, environmental damage, the affirmative culture of CNN, YouTube, pornography, Amazon.

It is tempting to conclude that there is nothing new under the sun; after all, Marx, Lenin and Trotsky all foresaw globalization as an endemic feature of modern economic imperialism. That there is nothing new is true in the sense that we are still struggling to defend social production for private consumption as the order of things, even as the world is driven by collective conflicts that never seem to lessen. Globalization, neoliberalism, marketization affirm a dismantling of welfare state benefits and governmental regulatory intervention at an historical moment when any hopes for the prospects of a socialist utopia have dropped almost entirely out of the public policy discourses for coping with the Great Recession.

And yet France just elected a Socialist president, suggesting that the branding of globalization has not completely succeeded - and never will, given the contradictory qualities of contemporary capitalism. Teleological explanations of the world derive from bourgeois social science's quest for immutable laws of progress that predict and then portray the realization of a harmonious totality as a necessary outcome of history. Bell (1976) announced the coming of a self-realizing future post-industrial age a decade before the Reagan Revolution started dismantling the very state management that kept American capitalism humming by regulating the money supply, creating jobs, investing in a permanent war economy, and redistributing a modicum of wealth so that the poor would continue shopping to prevent their revolt.

Occupy has this exactly correct: Corporate profiteering has rolled back the New Deal and proletarianized the middle class, who live from paycheck to paycheck as they amass more personal debt that forces them to continue living so precariously, including staggering student loans and underwater mortgages. Higher education, which produces Internet-era human capital such as "IT" personnel, has been privatized, changing the larger society's intellectual priorities from the cultivation of civic and cultural values to initiatives that directly benefit capital and the state. Neoliberalism thrives in our most valued example for entrepreneurial culture as organizations of all kinds, even schools and universities, are run on a putative "business model." Meanwhile, the public sphere (Habermas 1989; Calhoun 1993) becomes merely a cybersphere in which people "friend" each other, curate the archives of their electronic personae, and tweet their address book about the latest updates.

Marx understood that the only real business model in capitalism is desperate competition in the marketplace. Writing a hundred years after Adam Smith, Marx predicted that a few corporate giants, eventually replacing the robustness of market competition with oligopoly and monopoly, would squeeze small businesses out. This was unstable to Marx because capitalism cannot find work for the millions laid off by business failures, corporate consolidations and relentless automation. The unemployed cannot consume the products spewed out by giant Fordist industries, especially once the social safety net is ripped away in the name of more robust global competitiveness.

Unfettered markets produce, dialectically, progressive and regressive outcomes: We make food and literacy potentially available for everyone, but the rich get richer as hunger and ignorance become more common. Socialist movements (and here we include the white and black New Lefts of the 1960s) are the dialectical outcomes of this basic irrationality. The culture industry works overtime to flatten the present into utopian sufficiency, and continues the endless electronic warfare of infocommercials, robocalls and pop-ups all aimed at narcotizing people. But as all types of people experience economic crises on the individual level, the narcotic wears off. And, in the aftermath, we get many new social movements such as civil rights, the May Movement, the Prague Spring, the Arab Spring and 
now Occupy. These are all moments of a "new" - post-orthodox - Left that is, by now, over 50 years old. Early SDSers, such as Hayden and Flacks, memorialized all this in the timeless Port Huron Statement, which recommended "participatory democracy" as an alternative to the military-industrial complex.

By now, one would broaden the ambit of that oligarchical "complex" into the military-industrial-educationalentertainment complex, which is another way of noticing that base and superstructure, in Marx's terms, are interlocking and nearly nondifferentiable. "Nearly" is a key word, because one should unpack globalization as brand. The commodities being sold under its rubric are made alluring in today's warehouse-scale suburban sales clubs, but their everyday low prices rest upon free trade and sweatshops. Globalization, thus, is best read as world markets plus American mass culture, all made possible by the instantaneity of the Internet. Ironically, this reading of those raw realities can be, and frequently are, affirmed as entirely satisfactory to the corporate-leaning intellectuals in favor of such globalization and its brand.

This returns one to the issue of affirmative intellectual content; concepts that purport merely to describe actually endorse (perhaps by rendering these concepts ontological). That is the storyline of a positivism that pretends not to be narrative at all but to stand outside the world, and thereby reproducing it as our fate. Globalization is portrayed as a fate that we should love (Nietzsche's amor fati) because it is too difficult to imagine a "glocal" world (Luke 1994) in which we blend the premodern and postmodern to produce a utopian construct that has been aptly called the slowmodern (Agger 2004). Examples of slowmodernity include Petrini’s (2003) slow-food movement, redemption of nature, various mind-body healings that Agger outlines in his Body Problems (2010). The slowmodern endorses glocality as a transcendence of a spurious globalization that simply brands subordination to its peculiar New World Order (Luke, 1995) as standing for free trade coffee, Fords with Internet services on-board and Facebook friends.

Although neologisms cannot do our thinking for us, these new semantic blendings break away from the rhetorical ruts that affirmative culture bless as clear conceptualization and then suggest something about utopian possibility that negates/preserves/transcends the present - a Hegelian Aufhebung functioning dialectically, as new terminologies did for Marx. If globality bespeaks something about what early Marx called our species being, then one might get on board. But globality is a new brand of bureaucratized being that involves incredible new forms of hierarchy and inequality, as even the most casual glance at any of the many military and economic battlefields of the moment reveals. Accordingly, we need to occupy 'globalization' as we work to transform it from an affirmative into a critical concept. As it stands, globality is simply another way to talk about - and celebrate - late capitalism, while ignoring its many intrinsic miseries.

\section{References}

Agger, Ben. 2004. Speeding Up Fast Capitalism. Boulder: Paradigm.

------.2010. Body Problems. New York: Routledge.

Bell, Daniel 1976. The Coming of Post-Industrial Society. New York: Basic.

Calhoun, Craig. 1993. Habermas and the Public Sphere. Cambridge: MIT Press.

Habermas, Juergen. 1989. The Structural Transformation of the Public Sphere. Cambridge, Mass.: MIT Press.

Luke, Timothy W. 1995. "New World Order or Neo-World orders: Power, Politics, and Ideology in Informationalizing Glocalities," Global Modernities, eds. Mike Featherstone, Scott Lash, and Roland Robertson. London: Sage, 91-107.
Luke, Timothy W. 2004. "Placing Powers/Siting Spaces: The Politics of Global and Local in the New World Order." Environment and Planning D: Society and Space, 12 : 613-628.

Macpherson, C.B. 1970. The Political Theory of Possessive Individualism. Oxford: Oxford University Press.

Petrini, Carlos. 2003. Slow Food: The Case for Taste. New York: Columbia University Press. 
